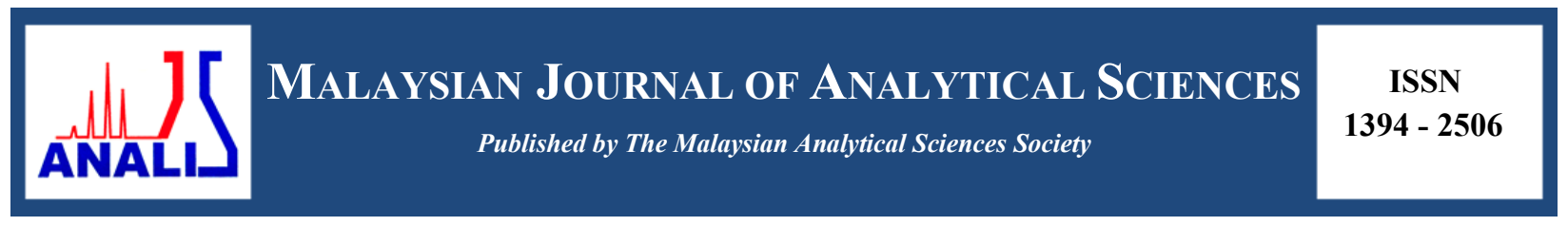

\title{
MICROEMULSION ELECTROKINETIC CHROMATOGRAPHY COUPLED WITH DISPERSIVE MICRO-SOLID PHASE EXTRACTION FOR DETERMINATION OF ISOFLAVONES IN SOYBEAN PRODUCTS
}

\author{
(Kromatografi Elektrokinetik Mikro-Emulsi Berganding dengan Pengekstrakan Fasa Pepejal \\ Mikro Serakan bagi Pengenalpastian Isoflavon di dalam Produk Kacang Soya) \\ Khaulah Ab Rahim ${ }^{1}$, Mohd Marsin Sanagi ${ }^{1,2}$, Dadan Hermawan ${ }^{3}$, Wan Aini Wan Ibrahim ${ }^{1,2}$, \\ Aemi Syazwani Abdul Keyon ${ }^{1}$ \\ ${ }^{1}$ Department of Chemistry, Faculty of Science \\ ${ }^{2}$ Centre for Sustainable Nanomaterials, Ibnu Sina Institute for Scientific and Industrial Research \\ Universiti Teknologi Malaysia, 81310 UTM Johor Bahru, Johor, Malaysia \\ ${ }^{3}$ Department of Chemistry, Faculty of Science and Engineering, \\ Universitas Jenderal Soedirman (UNSOED), Purwokerto, Indonesia \\ *Corresponding author: marsin@kimia.fs.utm.my
}

Received: 26 August 2017; Accepted: 27 December 2017

\begin{abstract}
A new method based on microemulsion electrokinetic chromatography (MEEKC) coupled with dispersive micro solid phase extraction (D- $\mu$-SPE) was developed for the determination of isoflavones in soy products. D- $\mu$-SPEs of real samples were carried out using multi-walled carbon nanotubes (MWCNTs) as adsorbent prior to MEEKC. Separations of selected isoflavones namely daidzein, genistein and formononetin by MEEKC were carried out using fresh daily-prepared microemulsion background electrolyte (BGE). The optimized MEEKC conditions for the separation of isoflavones were $4 \mathrm{mM}$ borate buffer $\mathrm{pH} 8.5,6.6 \%$ $(\mathrm{w} / \mathrm{v}) 1$-butanol, $0.9 \%(\mathrm{w} / \mathrm{v})$ sodium dodecyl sulphate, $0.75 \%(\mathrm{w} / \mathrm{v})$ ethyl acetate, $3 \%(\mathrm{w} / \mathrm{v})$ acetonitrile at $3 \mathrm{~s}$ injection time, 27 $\mathrm{kV}$ and $35{ }^{\circ} \mathrm{C}$. Meanwhile, the optimum D- $\mu$-SPE conditions were $5 \mathrm{mg}$ of MWCNTs and $300 \mu \mathrm{L}$ of methanol as desorption solvent. Under the optimized conditions, the developed D- $\mu$-SPE-MEEKC method showed good linearity in the concentration range of $1-10 \mathrm{mg} / \mathrm{L}$ with coefficients of determination $\left(r^{2}\right)>0.99$ and limits of detection of $0.27-0.95 \mathrm{mg} / \mathrm{L}$. The method was successfully applied to the determination of isoflavones in five soybean products namely soy supplement, tofu, tempeh, egg tofu and fujook and good recoveries were obtained in the range of $74.5-112.5 \%$ with RSDs of $<3 \%$. The method has proved to be simple and offers low consumption of organic solvent and relatively short analysis time, thus it is a potentially viable green alternative method for extraction and determination of isoflavones in soybean products.
\end{abstract}

Keywords: microemulsion electrokinetic chromatography, background electrolyte, dispersive micro solid phase extraction, isoflavones, soybean products

\footnotetext{
Abstrak

Satu kaedah baharu berasaskan kromatografi elektrokinetik mikroemulsi (MEEKC) berganding dengan pengekstrakan fasa pepejal mikro serakan (D- $\mu$-SPE) telah dibangunkan bagi menentukan isoflavon di dalam produk kacang soya. D- $\mu$-SPE sampel sebenar telah dijalankan menggunakan tiub nano karbon dinding berganda (MWCNT) sebagai penjerap sebelum MEEKC. Pemisahan isoflavon terpilih iaitu daidzein, genistein dan formononetin dengan MEEKC telah dijalankan menggunakan mikroemulsi elektrolit latar belakang (BGE) baharu yang disediakan setiap hari. Keadaan optimum MEEKC untuk pemisahan isoflavon ialah $4 \mathrm{mM}$ penimbal borat $\mathrm{pH} 8.5,6.6 \%(\mathrm{w} / \mathrm{v}) 1$-butanol, $0.9 \%(\mathrm{w} / \mathrm{v})$ natrium dodekil sulfat, $0.75 \%(\mathrm{w} / \mathrm{v})$ etil asetat, $3 \%(\mathrm{w} / \mathrm{v})$ asetonitril pada masa suntikan $3 \mathrm{~s}, 27 \mathrm{kV}$ dan $35^{\circ} \mathrm{C}$. Sementara itu, keadaan optimum untuk pengekstrakan ialah $5 \mathrm{mg}$
} 


\section{Khaulah et al: MICROEMULSION ELECTROKINETIC CHROMATOGRAPHY COUPLED WITH DISPERSIVE MICRO-SOLID PHASE EXTRACTION FOR DETERMINATION OF ISOFLAVONES IN SOYBEAN PRODUCTS}

MWCNT dan $300 \mu \mathrm{L}$ metanol sebagai pelarut penyaherapan. Di bawah keadaan optimum, kaedah D- $\mu$-SPE-MEEKC yang dibangunkan menunjukkan kelinearan yang baik dalam julat $1-10 \mathrm{mg} / \mathrm{L}$ dengan pekali penentuan $\left(r^{2}\right)>0.99$ dan had pengesanan 0.27-0.95 mg/L. Kaedah D- $\mu$-SPE-MEEKC telah berjaya digunakan dalam penentuan isoflavon di dalam lima produk soya iaitu makanan tambahan soya, tofu, tempe, tauhu telur dan kulit tauhu dengan kadar pengembalian $74.5-112.5 \%$ dan sisihan piawai relatif $(\mathrm{RSD})<3 \%$. Kaedah ini terbukti mudah dan ia menggunakan pelarut organik yang sedikit dan memberi masa analisis yang cepat, justeru berpotensi sebagai kaedah hijau berdaya saing bagi pengekstrakan dan penentuan isoflavon di dalam produk kacang soya.

Keywords: Kromatografi elektrokinetik mikroemulsi, elektrolit latar belakang, pengekstrakan fasa pepejal mikro serakan, isoflavon, produk kacang soya

\section{Introduction}

Nutritional supplements based on soy extract are rapidly growing segment in the food and health care market. Due to their content of phytoestrogens, these supplements are especially offered for postmenopausal women as an alternative to the traditional hormone replacement therapy [1,2]. Phytoestrogens are found in plants and food products as glycosidic conjugate. In fermented food, they are deconjugated to aglycones. Based on the structural similarity to the mammalian estrogen, isoflavones can bind to the receptors and show weak estrogenic activities [3]. Isoflavones is a class of organic compound and biomolecules related to the flavonoids and classified to four major subgroups according to their functional groups namely aglycones, glucosides, malonylglucosides and acetyl glucosides.

Isoflavones have been investigated in a number of clinical and in animal studies to determine their health protective effects. Isoflavones were reported to reduce the risk of cardiovascular disease, prostate, breast and colon cancer. In addition, isoflavones improve bone health by alleviating symptoms of osteoporosis which occurs after menopause. To date, 12 chemical forms of isoflavones have been found in soybeans [4], including 4-aglycones (major isoflavones in soybean) namely daidzein, genistein, glycitein and formononetin, 3 glucosides which are daidzin, genistin and glycitin [5]. The other forms of isoflavones are in malonylglucoside and acetyl glucoside groups. The basic characteristic isoflavone structure is a flavones nucleus, composed of two benzene rings linked to heterocyclic ring. The structure of some isoflavones component is shown in Figure 1.

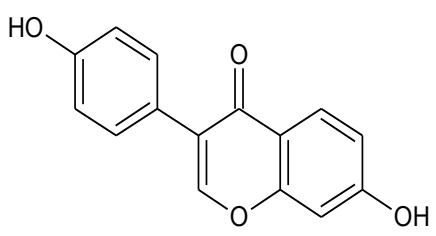

(a)<smiles>O=c1c(-c2ccc(O)cc2)coc2cc(O)cc(O)c12</smiles>

(b)<smiles>COc1ccc(-c2coc3cc(O)ccc3c2=O)cc1</smiles>

(c)

Figure 1. Structures of (a) daidzein, (b) genistein, and (c) formononetin

Several analytical methods to determine the isoflavones have been reported in the last few years including the high performance liquid chromatography (HPLC) with UV [6], gas chromatography (GC) coupled to mass spectrometry [7], and electrophoresis [8]. Among these methods, capillary electrophoresis has a great potential for the determination of isoflavones in soybean because it offers interesting advantages such as ease of automation, low solvent consumption, small sample volume, reproducible and high separation efficiency. 
Microemulsion electrokinetic chromatography (MEEKC) is a mode of capillary electrophoresis (CE). It is a technique that separates solutes based on their hydrophobicities and electrophoretic mobilities [9] which offers highly efficient separation of both charged and neutral solutes covering wide range of water solubility. It has been demonstrate as a reliable separation for both highly hydrophobic and hydrophilic compounds $[10,11,12]$. This technique uses an aqueous buffer containing droplet of oil, surfactant and co-surfactant to form a microemulsion background electrolyte (BGE) solution [13]. The most frequently used microemulsion BGE solution uses a waterimmiscible solvent (oil), such as $n$-heptane or $n$-octane and a surfactant such as sodium dodecyl sulfate (SDS) in an aqueous buffer such as borate or phosphate. A co-surfactant such as butanol is often added to improve the microemulsion stability.

Microemulsions are solution containing nano-meter size droplets of immiscible liquids dispersed in an aqueous buffer. Normally, the microemulsion droplets contain buffer, surfactant, co-surfactant, organic modifier and oil (ethyl acetate or $n$-octane) [14, 15]. The droplets are coated with surfactant to reduce the surface tension between the two liquid layers allowing an emulsion to form. The surface tension of the droplet is further lowered by the addition of short-chain alcohol, such as butanol, which stabilizes the system. The diameter of the oil droplets is below $10 \mathrm{~nm}$ giving an optically transparent emulsion; larger droplets would scatter light making an opaque emulsion [16].

A microemulsion containing ionic surfactant allows chromatographic separation to be obtained as solutes can partition between the charged oil droplets and the aqueous buffer phase. Water-insoluble compounds will favour inclusion into the oil droplets rather than into the buffer phase. The more hydrophobic the solute is, the more it will partition into the microemulsion droplet and the longer it will migrate to the detector.

Sample preparation is the most important part in chemical analysis. Extensive sample cleanup procedures are usually required to remove matrix components which may interfere the analysis. Dispersive micro solid phase extraction (D- $\mu$-SPE) allows the direct contact between the analytes with the sorbents because of the homogenous dispersion of the solid in the extract. In the present study, the applicability of D- $\mu$-SPE using carbon nanotube (CNT) as sorbents for the first time to simply extract daidzein, genistein and formononetin in soybean supplement and soybean food was investigated. The advantages of this technique are its easy miniaturization: small sample volume, less organic solvent and sorbent needed, short time requirement and convenience for efficiency of recovery.

This work was set out to develop an environmental friendly for analysis of isoflavones namely daidzein, genistein and formononetin using water in oil microemulsion electrokinetic chromatography (MEEKC) coupled with (D- $\mu-$ SPE). The method was validated and applied to the determination of isoflavones in soybean supplement and fermented soybean meal.

\section{Materials, method and instruments}

\section{Materials and Methods}

Standard of isoflavones (daidzein, genestein and formononetin) were purchased from Sigma-Aldrich (St. Louis, MO, USA). Sodium dodecyl sulfate (SDS) was purchased from Fischer Chemicals (Loughborough, Leics, UK) while sodium hydroxide, boric acid and sodium tetraborate anhydrous were purchased from Merck (Darmstadt, Germany). Methanol, 1-butanol, ethyl acetate and acetonitrile purchased from J.T Baker (Pennsylvania, USA). Deionized water was purified by Millipore Simplicity $\left(\operatorname{Simpak}^{\odot} 2\right)$.

Stock solutions of $1000 \mathrm{mg} / \mathrm{L}$ isoflavones (daidzein, genistein, formononetin) were prepared with methanol as solvent. Standard working solutions of 25, 50, 100 and $200 \mathrm{mg} / \mathrm{L}$ were prepared by diluting the stock solution with methanol. The stock solutions and all standards working solutions prepared were labelled and sealed to avoid evaporation of solution and stored in refrigerator until use.

An Agilent Technology Capillary Electrophoresis System (Wald-Bronn, Germany) equipped with diode array detection (DAD) operating at $254 \mathrm{~nm}$ was used. An uncoated fused-silica capillary of $50 \mu \mathrm{m}$ inner diameter (I.D) with a total length of $64.5 \mathrm{~cm}$ (56 cm to detector) was used for the separation process. Each new capillary used was 


\section{Khaulah et al: MICROEMULSION ELECTROKINETIC CHROMATOGRAPHY COUPLED WITH DISPERSIVE MICRO-SOLID PHASE EXTRACTION FOR DETERMINATION OF ISOFLAVONES IN SOYBEAN PRODUCTS}

conditioned for 10 min with $1.0 \mathrm{~N} \mathrm{NaOH}$ and then equilibrated with Milli-Q water for $30 \mathrm{~min}$, followed by $0.1 \mathrm{~N}$ $\mathrm{NaOH}$ for $30 \mathrm{~min}$, after that Milli-Q water for $30 \mathrm{~min}$, and finally with background electrolyte (BGE) for $30 \mathrm{~min}$. The capillary was pre-conditioned for 2 min with BGE and post-conditioned with $0.1 \mathrm{~N} \mathrm{NaOH}$ and Milli-Q water for $2 \mathrm{~min}$ between analyses. When the capillary was not in use, it was flushed using air for $5 \mathrm{~min}$ and stored.

\section{Preparation of microemulsions}

Sodium tetraborate buffer $(4 \mathrm{mM})$ was prepared by dissolving $0.9534 \mathrm{~g}$ of sodium tetraborate anhydrous using deionized water in a $250-\mathrm{mL}$ volumetric flask.The buffer solution was diluted to the mark after the solution was adjusted to $\mathrm{pH} 8.5$ using $2 \mathrm{M}$ boric acid. Microemulsions (ME) were prepared as follows: $17.75 \mathrm{~g}$ of buffer and 0.18 $\mathrm{g}$ surfactant (SDS) were mixed. Subsequently, $0.15 \mathrm{~g}$ of oil (ethyl acetate), $1.32 \mathrm{~g}$ co-surfactant (1-butanol) and 0.6 $\mathrm{g}$ of organic modifier (acetonitrile) were added. The solution obtained was sonicated for 20 minutes to aid the dissolution. The ME solution was filtered through $0.22 \mu \mathrm{m}$ nylon syringe to remove impurities. All of the ME solutions used in this research were prepared using similar method daily.

\section{Sample pretreatment and extraction procedure}

The dispersive- $\mu$-solid phase extraction (D- $\mu$-SPE) procedure used in this study was adopted from a previous study [17] with some modifications. The proteins and fats in $10 \mathrm{~mL}$ samples were precipitated by shaking vigorously with $3 \mathrm{~mL}$ of a mixture of acetone and acetonitrile $(2: 1, \mathrm{v} / \mathrm{v})$. The solution was then centrifuge at $4000 \mathrm{rpm}$ for 5 minutes. The supernatant was evaporated in a nitrogen atmosphere to eliminate the organic solvents. The D- $\mu$-SPE procedure involved immersing $5 \mathrm{mg}$ of carbon nanotube (CNT) in a $10 \mathrm{~mL}$ of the deproteinized sample in a centrifuge tube. After 10 minutes of extraction by vigorous shaking using vortex and centrifuge at maximum speed, the adsorbents were collected and desorbed with $300 \mu \mathrm{L}$ of methanol. After incubation for 5 minutes, the adsorbent were filtered and easily removed by filter device $(0.45 \mu \mathrm{m})$ from the desorption solvent. The extract was then directly injected to $\mathrm{CE}$ for analysis.

\section{Optimization of MEEKC system}

\section{Results and Discussion}

A microemulsion composed of SDS, 1-butanol, ethyl acetate and aqueous buffer has been the most frequently used electrophoretic medium in MEEKC [10]. Therefore, this mixture was selected to explore the potential of MEEKC to determine the isoflavones in soybean. The influence of specific parameters such as surfactant concentration, cosurfactant, organic modifier and oil, applied voltage, $\mathrm{pH}$ buffer, injection time and temperature were systematically investigated.

\section{Effect of applied voltage, temperature and injection time}

The capillary temperature can affect solute stability which is related to the partitioning coefficient. The electrophoretic mobility of an ion is also affected by temperature [3]. The temperature leads to a reduction of migration times by decreasing the buffer viscosity. This phenomenon can be explained with the increasing of EOF when higher temperature is applied into the microemulsion system. When the EOF was increased, the migration time of the analyte decreased due to the strong sweeping process of the analyte towards the cathode by the EOF. However, higher temperature could enhance the band broadening and decrease the peak efficiency [18]. Considering the migration time, temperature of $35^{\circ} \mathrm{C}$ was selected as the best condition for the determination of isoflavones using MEEKC method.

Meanwhile, the effect of applied voltage in the range of $25-30 \mathrm{kV}$ was studied. Application of higher voltage (30 $\mathrm{kV}$ ) has resulted in obvious decrease in the resolution due to the increased Joule heating. However, use of lower voltage $(25 \mathrm{kV})$ resulted in longer migration times. Therefore, the optimum voltage for analysis was chosen at 27 $\mathrm{kV}$ as it gave faster analysis time and greater peak area. Figure 1 shows the effect of applied voltage to peak area. Higher applied voltage may damage the capillary used due to Joule heating. 


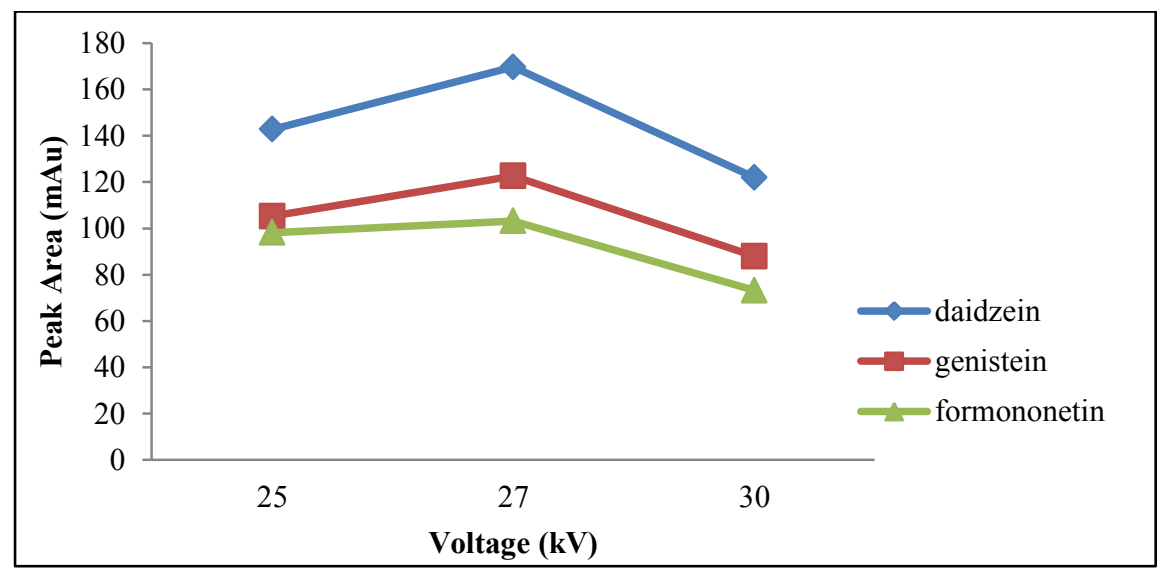

Figure 1. Effect of voltage on peak area on $\operatorname{MEEKC~}(n=3$ in each case)

A small sample zone and short injection time reduce band broadening and maintain efficient peaks with high plate numbers. This improves injection volume precision but only works well if the injection time is at least $3 \mathrm{~s}$. In this study, the injection time was varied in the range of 2-5 s. Apparently; shorter injection time resulted in improved resolution of the peaks. At higher injection time, the isoflavones were not well-separated because of the excessive amounts of analyte per injection. Thus, $3 \mathrm{~s}$ was selected to be the optimum injection time.

\section{Effect of composition in background electrolyte: Effect of buffer $\mathrm{pH}$, buffer, surfactant and co-surfactant concentration \\ Buffer $\mathrm{pH}$ influences the degree of capillary ionization and hence the EOF velocity. At high $\mathrm{pH}$, the EOF may be so rapid that incomplete separations may occur. However, at lower $\mathrm{pH}$ where the EOF is greatly reduced, both cations and anions can be measured [19]. In this work, with the concentration of $10 \mathrm{mM}$ borate buffer unchanged, different $\mathrm{pH}$ values ranging from 8-9 were tested. Taking into account the resolution, peak area and migration time, $\mathrm{pH} 8.5$ was chosen for subsequent experiments.}

Generally, MEEKC was performed using low ionic strength of borate or phosphate buffer. These generate relatively low currents and a reasonably fast EOF. Higher buffer concentrations suppress the EOF and generate high currents which may limit the level of voltage that can be applied. In optimizing the MEEKC of isoflavones, the buffer concentration in the range of 3-5 mM was investigated. Taking into account the migration time and the peak area, $4 \mathrm{mM}$ buffer concentration was chosen as the optimum and used in subsequent experiments.

Surfactant plays main role in lowering the surface tension between the oil and aqueous phase of ME. SDS is anionic surfactant which penetrates into the oil droplet. The choice of surfactant has a marked effect on the separation achieved in MEEKC as it affects the oil droplet charge and size, the level and direction of EOF [3]. Increasing the surfactant concentration will increases the ionic strength of the buffer which reduces the EOF level and increase analysis time. SDS concentrations ranging of $0.8-1.0 \% \mathrm{w} / \mathrm{w}$ were investigated for optimization study. Figure 2 shows the effect of SDS concentration towards migration time. The fastest migration time was obtained at concentration of SDS of 0.9 .

The size of oil droplet increases with increased co-surfactant concentration that will affect the charge density of the droplet. Studies have shown that the separation selectivity is unaltered [9] by variation of 1-butanol concentration. Higher 1-butanol concentration reduces migration times for water insoluble solute but do not alter the capacity factors. The migration times are altered with varying co-surfactant concentration as it affects the solution viscosity which in turns affects the EOF rate. Even though 3.3\% 1-butanol concentration gave the fastest migration time, the peak area and peak height is the lowest. The optimum condition for separation of isoflavones was achieved using $6.6 \%$ 1-butanol concentration. Table 1 summarizes the MEEKC parameters optimized in this work. 


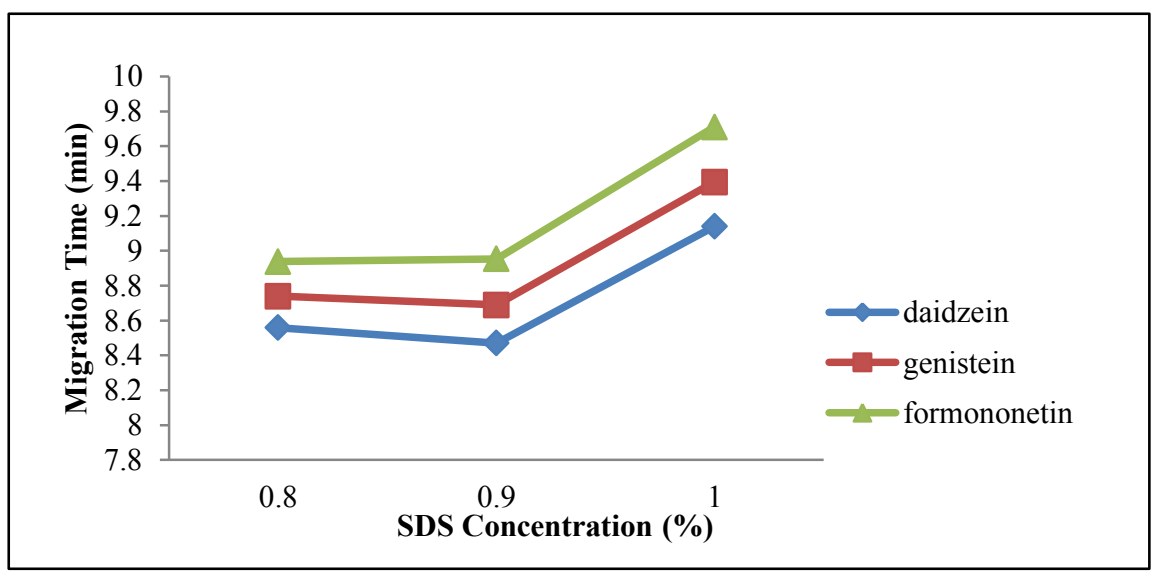

Figure 2. Effect of SDS concentration on migration time

Table 1. Parameters evaluated in the MEEKC system

\begin{tabular}{lc}
\hline Parameters & Optimized Condition \\
\hline Applied voltage $(\mathrm{kV})$ & 27 \\
Temperature $\left({ }^{\circ} \mathrm{C}\right)$ & 35 \\
Injection time $(\mathrm{s})$ & 3 \\
pH buffer & 8.5 \\
Buffer concentration $(\%)$ & 88.75 \\
SDS concentration $(\%)$ & 0.9 \\
1-butanol concentration $(\%)$ & 6.6 \\
Acetonitrile concentration $(\%)$ & 3 \\
Ethyl acetate concentration $(\%)$ & 0.75 \\
\hline
\end{tabular}

\section{Optimization of D- $\mu$-SPE}

According to previous studies [20,17], there are three important parameters that affect the extraction efficiency of D- $\mu$-SPE: type of adsorbent, amount of adsorbent and type of desorption solvent. Optimization was carried out in triplicate using spiked deionized water spiked with daidzein, genistein and formononetin at a concentration of $1 \mu \mathrm{g}$ $\mathrm{mL}^{-1}$.

The first parameter studied was the type of adsorbent. For this purpose, three different adsorbents namely multiwalled carbon nanotubes (MWCNT), primary secondary amine (PSA) and octadecyl-silylsilica (C18) were evaluated. Ideal carbonaceous adsorbent should have large surface area to enhance the adsorption efficiency and extraction characteristics of the organic compounds from aqueous solutions. CNT offered the best peak area after extraction of isoflavones as it has high surface area, chemical stability and mechanical strength [21]. The ability of CNT to establish $\pi-\pi$ interactions as well as excellent Van der Waals interaction with hydrophobic molecules (existence of aromatic ring) make them suitable for the extraction of isoflavones. Many applications of CNT as sorbent have been reported for extraction such as herbicide in tobacco [22], pesticide from water [20] and nitrosamines in meat products [17]. To our best knowledge, no work has been reported on the use of MWCNT as sorbent for the extraction of isoflavones from soybean products.

Amount of sorbent was studied in this work. The quantity of CNT added into the sample was varied between 1 and $7 \mathrm{mg}$. As expected, the peak area increased as the amount of adsorbent increased up to $5 \mathrm{mg}$. However, when $7 \mathrm{mg}$ 
MWCNT was added, the peak area of daidzein, genistein and formononetin decrease. Therefore, $5 \mathrm{mg}$ of MWCNT was chosen as optimum amount of adsorbent as the recovery values are acceptable (104-117\%).

Once the analytes have been extracted, they should be eluted for the analysis. Four commonly used desorption solvent (methanol, acetonitrile, isopropanol and ethanol) were evaluated in this work. Methanol provides the best and more reproducible recovery values and the relative standard deviations were acceptable in all assays with values lower than $2.1 \%$. The effect of desorption solvent to the peak area is shown in Figure 3. $300 \mu \mathrm{L}$ of methanol provided the best elution in terms of precision and sensitivity. Although isopropanol showed the highest peak area, it was not chosen because it resulted in noisy baselines that became worse with repeated injections probably due to interferences from impurities.

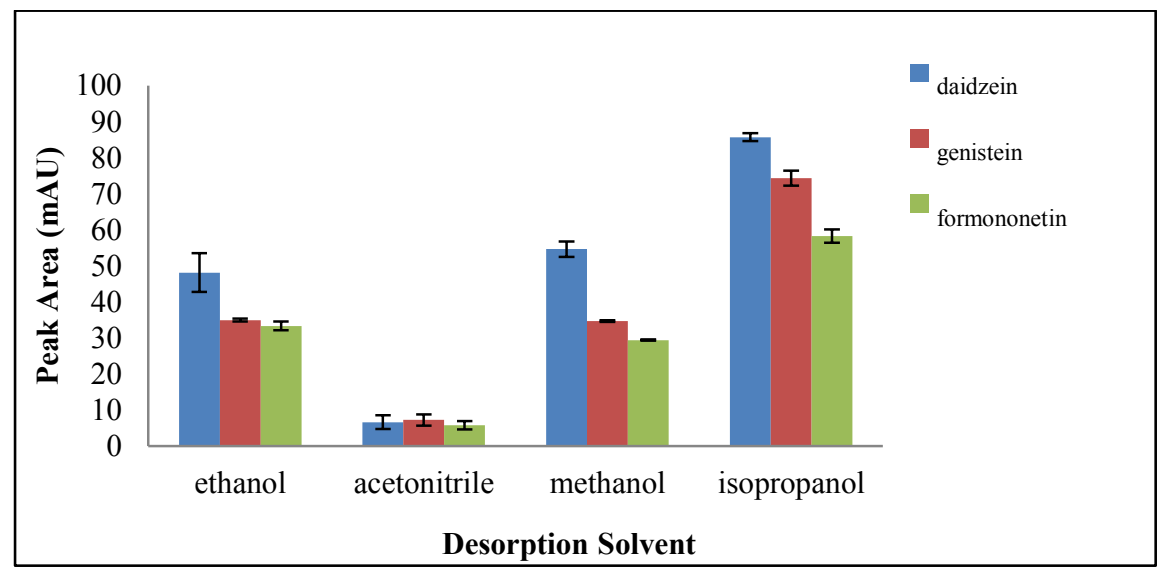

Figure 3. Effect of desorption solvent on peak area

\section{Method validation}

In order to determine the linearity and precision of the method, a series of standard solutions of the three isoflavones at concentrations in the range of $1-10 \mu \mathrm{g} / \mathrm{mL}$ were analyzed. In general, the three targeted analytes were successfully separated with good resolution. Results from regression analysis of three calibration curves and detection limits are presented in Table 2 . The RSD values were $<3.35 \%$, which indicated that the method enabled the accurate simultaneous determination of the three analytes.

The detection limits were evaluated on the basis of a single-to-noise ratio of 3:1. Under the optimized conditions, the calibration curves of the isoflavones showed good linearity in the concentration range of $10-100 \mu \mathrm{g} / \mathrm{mL}$ with coefficients of determination $\left(\mathrm{r}^{2}\right)>0.99$ and limit of detections range from $0.27 \mu \mathrm{g} / \mathrm{mL}$ to $0.95 \mu \mathrm{g} / \mathrm{mL}$.

A standard mixture solution of three isoflavones was determined in triplicate in order to determine the reproducibility of the peak area and migration time for all analytes under optimum conditions.

Table 2. Parameters for the extraction standard curves for isoflavones

\begin{tabular}{llcccc}
\hline Compound & $\begin{array}{l}\text { Regression } \\
\text { Equation }\end{array}$ & $\begin{array}{c}\text { Correlation } \\
\text { Coefficient }\end{array}$ & $\begin{array}{c}\text { Linear Range } \\
(\boldsymbol{\mu g} / \mathbf{m L})\end{array}$ & $\begin{array}{c}\text { Detection Limit } \\
(\boldsymbol{\mu g} / \mathbf{m L})\end{array}$ & RSD (\%) \\
\hline Daidzein & $\mathrm{y}=10.056 \mathrm{x}$ & 0.9922 & $1-10$ & 0.95 & 1.49 \\
Genistein & $\mathrm{y}=7.7467 \mathrm{x}-6.0181$ & 0.9969 & $1-10$ & 0.58 & 3.35 \\
Formononetin & $\mathrm{y}=6.8084 \mathrm{x}-4.8344$ & 0.9995 & $1-10$ & 0.27 & 1.67 \\
\hline
\end{tabular}




\section{Analyte recovery}

Accurate amounts of three standards were added into the real soybean meal samples with known contents of the desired compounds. The mixtures prepared using the same method as described in the sample pretreatment and extraction procedure section were analyzed using the developed MEEKC method. The percentage analyte recoveries are shown in Table 3. Under the optimized conditions, the recoveries of the investigated compounds ranged from 104.6-120.0\%, with RSDs $<2.2 \%$ which indicated that the method enabled the accurate simultaneous determination of the three analytes.

Table 3. Recoveries of three isoflavones $(n=3)$

\begin{tabular}{llll}
\hline Sample & Compound & Recovery (\%) & RSD (\%) \\
\hline Tempeh & Daidzein & 120.0 & 1.25 \\
& Genistein & 119.0 & 2.11 \\
& Formononetin & 112.9 & 0.96 \\
Soy supplement & Daidzein & 107 & 1.23 \\
& Genistein & 117.7 & 1.42 \\
& Formononetin & 104.6 & 0.91 \\
\hline
\end{tabular}

\section{Application of D- $\mu$-SPE-MEEKC to soybean products}

The develop method was applied to two samples namely tempeh and soy supplement. Both samples were purchased from local market in Johor, Malaysia. The three target isoflavones were all successfully baseline-separated within 8 minutes. Typical electropherograms of the separation of standard isoflavones and extracted isoflavones from samples are shown in Figure 4. It was found that higher amount of genistein, daidzein and formononetin extracted in soy supplement than tempeh. This might be due to the fermentation process and heat supply during the process [23]. Higher recoveries of extraction of the aglycones in tempeh (112.9-120\%) and soy supplement (104.6-117.7\%) showing that this technique has a lot of potential in the determination of isoflavones in other soy food.
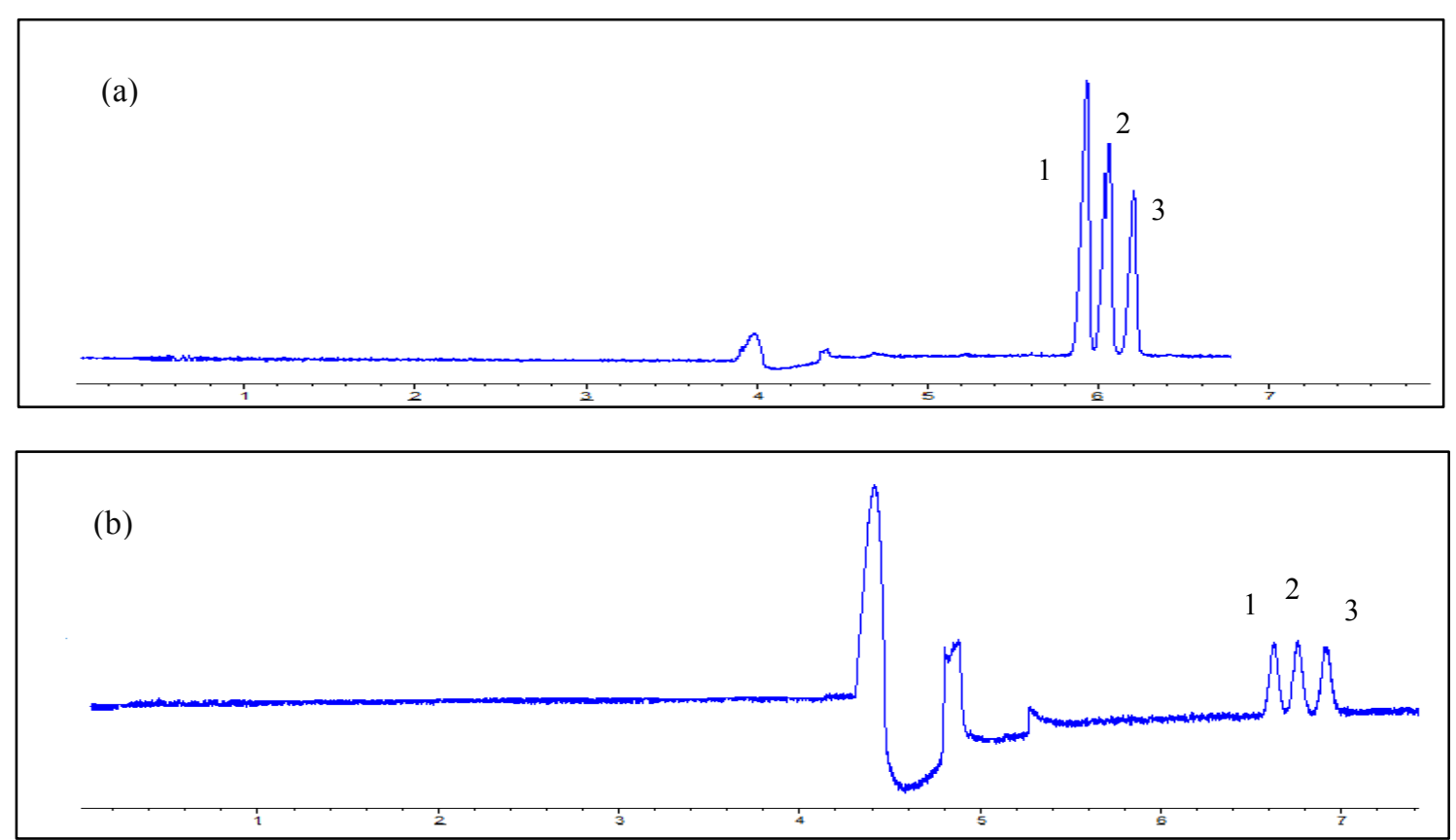

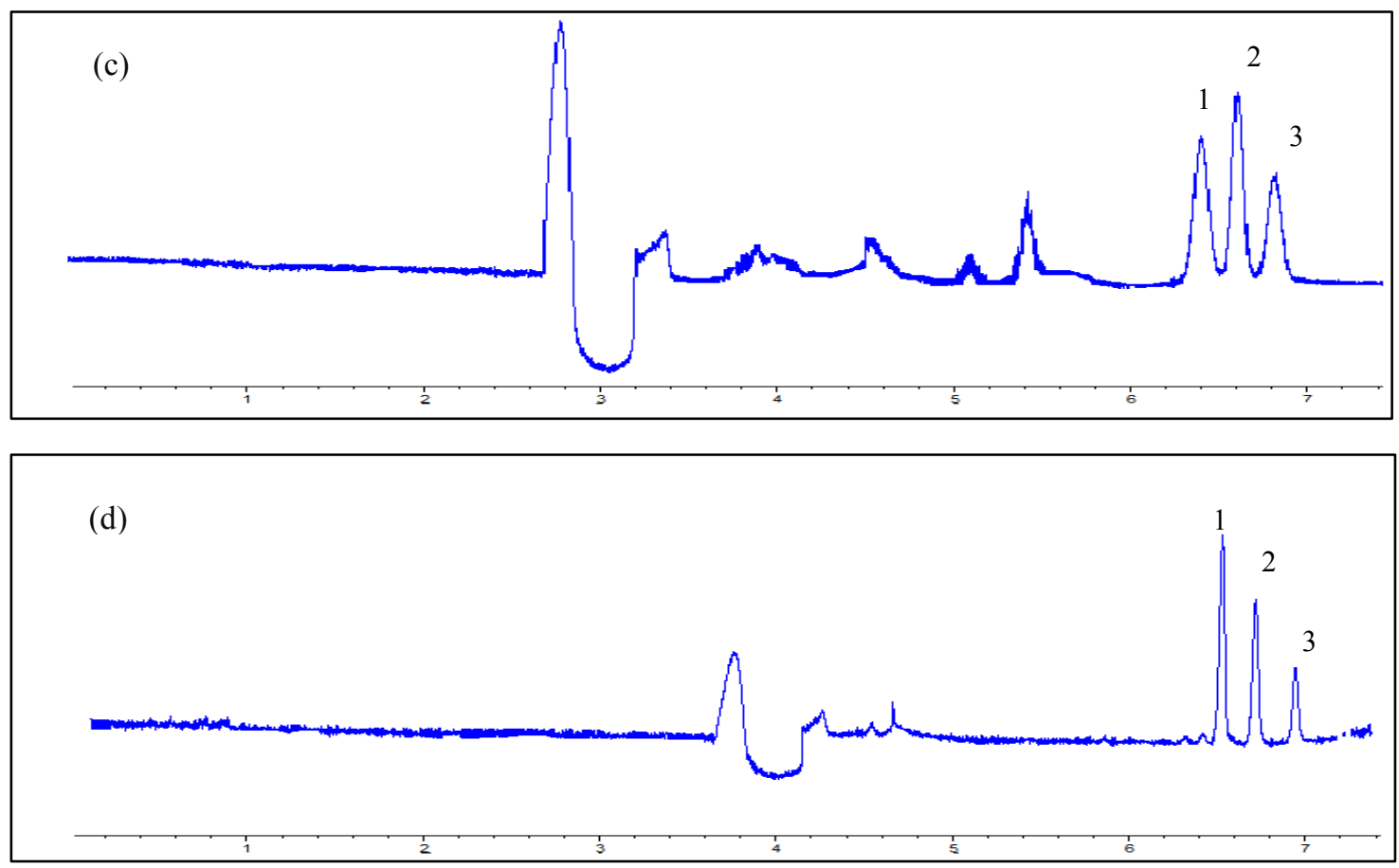

Figure 4. Electropherograms for isoflavones (a) standard mixture solution $(100 \mu \mathrm{g} / \mathrm{mL})$, (b) standard mixture solution after extraction $(10 \mu \mathrm{g} / \mathrm{mL})$, (c) soy supplement and (d) tempeh. Running buffer: $4 \mathrm{mM}$ borate buffer $\mathrm{pH} 8.5,6.6 \% 1$-butanol, $0.9 \%$ sodium dodecyl sulpahate, $0.75 \%$ ethyl acetate, $3 \%$ acetonitrile at $3 \mathrm{~s}$ injection time, $27 \mathrm{kV}$ and $35^{\circ} \mathrm{C}$. Peak identities: $1=$ genistein, $2=$ daidzein, $3=$ formononetin

\section{Conclusion}

A newly developed MEEKC method combine with D- $\mu$-SPE was applicable for the determination of isoflavones in soybean meal and supplement. Three isoflavones were successfully separated within 8 minutes, which is three times faster than reported work by Xiao et al. [8]. Minimum usage of organic solvent and small sample volume make this method environmental friendly. The high recoveries and low RSD values demonstrated in this study proved that MEEKC-D- $\mu$-SPE is capable to become a new technique for determination of isoflavones.

\section{Acknowledgement}

The authors would like to thank Universiti Teknologi Malaysia and the Ministry of Higher Education Malaysia (MOHE) for financial supports through research grants number Q.J130000.2526.03H79 and R.J130000.7809.4F177 and studentship for Khaulah Ab Rahim.

\section{References}

1. Rangel, M. B., Zamarreno, M. M. D., Martinez, R. C. and Alvarez, J. D. (2012). Analysis of isoflavones in soy drink by capillary electrophoresis coupled with electrospray ionization mass spectrometry. Analytica Chimica Acta, 709: 113 - 119 .

2. Achouri, A., Boye, J. I. and Belanger, D. (2005). Soybean isoflavones: Efficiency of extraction conditions and effect of food type on extractability. Food Research International, 38: 1199- 1204.

3. Sturtz, M., Lander, V., Schimd, W. and Winhalter, P. (2008). Quantitative determination of isoflavones in soy based nutritional supplements by high-performance liquid chromatography. Journal of Consumer Protection and Food Safety, 3: $127-136$. 
Khaulah et al: MICROEMULSION ELECTROKINETIC CHROMATOGRAPHY COUPLED WITH DISPERSIVE MICRO-SOLID PHASE EXTRACTION FOR DETERMINATION OF ISOFLAVONES IN SOYBEAN PRODUCTS

4. Taku, K., Melby, K. M., Takebayashi, J., Mizuno, S., Ishimi, Y., Omori. T. and Watanabe, S. (2010). Effect of soy isoflavone extract supplements on bone mineral density in menopausal women: meta-analysis of randomized controlled trials. Asia Pacific Journal of Clinical Nutrition, 19: 33 - 42.

5. Ming, S. J., Li, S. B., Rong, Y. S, Hua. Y. and Kikuchi, A. (2011). Rapid HPLC method for determination of 12 isoflavone components in soybean seeds. Agricultural Sciences in China, 1:70 - 77.

6. Garc'ia, M. C., Marina, M. L. and Torre, M. (2000). Determination by perfusion reversed-phase highperformance liquid chromatography of the soybean protein content of commercial soybean products prepared directly from whole soybeans. Journal of Chromatography A, 880:37-46.

7. Magiera, S., Uhlschmied, C., Rainerb, M., Huck, C. W., Baranowska, I. and Bonn, G. K. (2011). GC-MS method for the simultaneous determination of blockers, flavonoids, isoflavones and their metabolites in human urine. Journal of Pharmaceutical and Biomedical Analysis, 56: 93 - 102.

8. Xiao, M., Ye, J., Tang, X. and Huang, Y. (2011). Determination of soybean isoflavones in soybean meal and fermented soybean meal by micellar electrokinetic capillary chromatography. Food Chemistry, 126: 1488 1492.

9. Altria, K. D. (2000). Background theory and applications of microemulsion electrokinetic chromatography. Journal of Chromatography A, 892: $171-186$.

10. Mahuzier, P. E., Aurora, M. S., Clark, B. J., Hackmann, E. R. M. and Altria, K. D. (2003). An introduction to the theory and application of microemulsion electrokinetic chromatography. LC-GC Europe, 16(1): $22-29$.

11. Jandera, P., Fischer, J., Jebava, J. and Effenberger, H. (2001). Characterization of retention in micellar high performance liquid chromatography and in micellar electrokinetic chromatography with reduced flow. Journal of Chromatography, 914: 233 - 244

12. Nakamura, H., Sano, A. and Matsuura, K. (1998). Determination of micelle concentration of anionic surfactant by capillary electrophoresis using 2-naphthalenemethanol as a marker for micelle formation. Journal of Analytical Science, 14, 379-372

13. Puyana, M. C., Crego, A. L. and Marina, M. L. (2008). Recent advances in the analysis of antibiotics by CE and CEC. Electrophoresis, 29: $274-293$.

14. McEvoy, E., Marsh, A., Altria, K., Donegan, S. and Power, J. (2007). Recent advances in the development and application of microemulsion EKC. Electrophoresis, 28: 193 - 207.

15. Ryan, R., Altria, K.D., Donegan, S. and Power, J. (2013). Developments in the methodology and application of microemulsion electrokinetic chromatography. Electrophoresis, 34: 154-177.

16. Chuerkaoui, S. and Veuthey, J. L. (2002). Micellar and microemulsion electrokinetic chromatography of selected anesthetic drugs. Journal of Separation Science, 25: 1073 - 1078.

17. Huang, M. C., Chen, H. C., Fu, S. C. and Ding, W. H. (2013). Determination of volatile $n$-nitrosamines in meat products by microwave-assisted extraction coupled with dispersive micro solid-phase extraction and gas chromatography- chemical ionization mass spectrometry. Food Chemistry, 138: 227 - 233.

18. Miola, F. M., Snowden, M. J. and Altria, K. D. (1998). The use of microemulsion electrokinetic chromatography in pharmaceutical analysis. Journal of Pharmaceutical and Biomedical Analysis, 18: 785 797.

19. Himmelsbach, M., Haunschmidt, M., Buchberger, W. and Klampfl, C. W. (2007). Microemulsion electrokinetic chromatography with on-line atmospheric pressure. Analytical Chemistry, 79: 1564 - 1568.

20. Soto, J. M. J., Cardenas, S. and Valcarcel, M. (2012). Dispersive micro solid-phase extraction of triazines from waters using oxidized single-walled carbon nanohorns as sorbent. Journal of Chromatography A, 1245: 17 23.

21. Zhou, Y. G., Chen, X. H., Pan. S. D., Zhu, H. and Shen, H. Y. (2013). Simultaneous analysis of eight phenolic environmental estrogens in blood using dispersive micro-solid-phase extraction combined with ultra-fast liquid chromatography-tandem mass spectrometry. Talanta, 115: 787 - 797.

22. Liao, Q. G., Zhou, Y. M., Luo L. G., Wang, L. B. and Feng, H. X. (2014). Determination of twelve herbicides in tobacco by a combination of solid-liquid-solid dispersive extraction using multi-walled carbon nanotubes, dispersive liquid-liquid micro-extraction, and detection by GC with triple quadrupole mass spectrometry. Microchimica Acta, 181: 163 - 169.

23. Murphy, P. A., Barua, K. and Hauck, C. C. (2002). Solvent extraction selection in the determination of isoflavones in soy foods. Journal of Chromatography B, 777: 129 - 138. 